\title{
Water-Table and Potentiometric-Surface Altitudes in the Upper Glacial, Magothy, and Lloyd Aquifers beneath Long Island, New York, March-April 2006
}

\author{
By Jack Monti, Jr., and Ronald Busciolano, U.S. Geological Survey, Coram, New York
}

\section{Introduction}

The U.S. Geological Survey (USGS), in cooperation with State and local agencies, systematically collects ground-water data at varying measurement frequencies to monitor the hydrologic situation on Long Island, New York. Each year during March and April, the USGS conducts a synoptic survey of hydrologic conditions to define the spatial distribution of the water table and potentiometric surfaces within the three main water-bearing units underlying Long Island - the upper glacial, Magothy, and Lloyd aquifers. These data and the maps constructed from them are commonly used in studies of Long Island's hydrology, and by water managers and suppliers for aquifer management and planning purposes.

Water-level measurements made in 502 wells across Long Island during March-April 2006, were used to prepare the maps in this report. Measurements were made by the wetted-tape method to the nearest hundredth of a foot. Water-table and potentiometric-surface altitudes in these aquifers were contoured using these measurements. The water-table contours were interpreted using water-level data collected from 341 wells screened in the upper glacial aquifer and (or) shallow Magothy aquifer; the Magothy aquifer's potentiometric-surface contours were interpreted from measurements at 102 wells screened in the middle to deep Magothy aquifer and (or) contiguous and hydraulically connected Jameco aquifer; and the Lloyd aquifer's potentiometric-surface contours were interpreted from measurements at 59 wells screened in the Lloyd aquifer or contiguous and hydraulically connected North Shore aquifer. Many of the supply wells are in continuous operation and, therefore, were turned off for a minimum of 24 hours before measurements were made so that the water levels in the wells could recover to the level of the potentiometric head in the surrounding aquifer. Full recovery time at some of these supply wells can exceed 24 hours; therefore, water levels measured at these wells are assumed to be less accurate than those measured at observation wells, which are not pumped. In this report, all water-level altitudes are referenced to the National Geodetic Vertical Datum of 1929 (NGVD 29).

\section{Upper Glacial Aquifer}

The upper glacial aquifer of Pleistocene age is the uppermost unit in Long Island's ground-water system and contains the water table throughout the island, except in parts of central and eastern Nassau County and western Suffolk County, where the entire unit is unsaturated. The upper glacial aquifer was the principal source of water supply throughout Long Island for several decades, but contamination in many areas resulted in the widespread curtailment of its use for 
public supply. The general configuration of the water table is an east-west mound that coincides with the glacial moraine along the center of the island, with an isolated high in central Nassau County and another in central Suffolk County (Sheet 1 - Water table (PDF 39.4MB)). Local highs also are present in northwestern Nassau County and the central part of the southern peninsula of eastern Suffolk County. These highs are a result of the low hydraulic conductivity of the geologic units.

The water-table altitude on Long Island in 2006 ranged from NGVD 29 along the shore to more than $120 \mathrm{ft}$ above NGVD 29 in northwestern Nassau County. In Kings County, 26 measurements ranged from 0.97 to $17.10 \mathrm{ft}$; in Queens County, 43 measurements ranged from 3.45 to $46.89 \mathrm{ft}$; in Nassau County 71 measurements ranged from 5.35 to $123.35 \mathrm{ft}$; and in Suffolk County 201 measurements ranged from 0.86 to $82.19 \mathrm{ft}$ above NGVD 29.

\section{Magothy and Jameco Aquifers}

The Magothy aquifer of upper Cretaceous age is the most extensive unit in Long Island's ground-water system. This aquifer underlies most of Long Island and the offshore waters except in parts of western and northern Kings and Queens Counties, northern Nassau County, and northwestern and northeastern Suffolk County, where it has been removed by erosion and glacial scour. The altitude of its upper surface ranges from more than $200 \mathrm{ft}$ above NGVD 29 in parts of north-central Nassau County and west-central Suffolk County to more than $600 \mathrm{ft}$ below NGVD 29 in north-central Suffolk County (Smolensky and others, 1989). Aquifer thickness ranges from zero in northern and western Kings and Queens Counties, northern Nassau County, and parts of northern Suffolk County to more than 1,000 ft in south-central Suffolk County (Soren and Simmons, 1987). The Magothy aquifer has become the principal source of water supply in Nassau and Suffolk Counties during the past 50 years as a result of contamination in the upper glacial aquifer.

This map depicts the non-pumping water levels in March-April 2006 in wells screened in the Magothy aquifer and the hydraulically connected Jameco aquifer (in parts of western Long Island) (Sheet 2 - Potentiometric surface in the Magothy and Jameco aquifers (PDF 33.6 MB)). Most water-level measurements used to prepare this map were made in wells screened near the middle of the aquifer, supplemented by some measurements from the basal zone. Only a few measurements made in the upper part were used. Because vertical hydraulic gradients in the Magothy aquifer can be large, measured potentiometric heads at a given location can vary depending on the depth of the well screen.

The general configuration of the potentiometric surface in the Magothy aquifer is similar to that of the water table, rising gradually from the western part of Long Island to form an eastwest-trending mound in Nassau and western Suffolk Counties. The surface of the mound then gradually declines toward the eastern end of Long Island. In areas where deep channels have been eroded into the Magothy aquifer and filled with glacial deposits, the potentiometric-surface contours were drawn from water levels measured in wells screened in these upper glacial aquifer deposits, which are laterally contiguous and hydraulically connected with the Magothy aquifer. The northern limit of the Magothy aquifer, the extent of the Jameco aquifer, and the aquifer in which each well is screened are indicated on this map.

The altitude of the potentiometric surface in the Magothy aquifer on Long Island in 2006 ranged from about $3 \mathrm{ft}$ below NGVD 29 in extreme southwestern Nassau County to more than 70 $\mathrm{ft}$ above NGVD 29 in northeastern Nassau County. In Kings County, 3 measurements ranged from 0.69 to $3.23 \mathrm{ft}$; in Queens County, 7 measurements ranged from 3.80 to $26.35 \mathrm{ft}$; in Nassau 
County, 31 measurements ranged from -3.00 to $79.58 \mathrm{ft}$; and in Suffolk County, 61 measurements ranged from 5.86 to $77.59 \mathrm{ft}$ above NGVD 29.

\section{Lloyd and North Shore Aquifers}

The Lloyd aquifer of upper Cretaceous age is the basal unit of Long Island's groundwater system. This aquifer continuously underlies most of Long Island and the offshore waters, except in parts of western and northern Kings, Queens, and Nassau Counties, and extreme northeastern Suffolk County, where it has been removed by erosion. The altitude of the aquifers upper surface ranges from less than $100 \mathrm{ft}$ below NGVD 29 in extreme northern parts of Queens County to more than 1,500 ft below NGVD 29 in south-central Suffolk County (Smolensky and others, 1989). Aquifer thickness ranges from zero in northern and western parts of Kings, Queens, and Nassau Counties and extreme northeastern Suffolk County to more than $500 \mathrm{ft}$ in extreme southeastern Nassau and southwestern Suffolk Counties (Soren and Simmons, 1987). The Lloyd aquifer has become increasingly important as a source of water supply in some parts of Long Island in recent decades.

This map depicts non-pumping water levels in March-April 2006 in 59 wells screened in the Lloyd and North Shore aquifers (Sheet 3 - Potentiometric surface in the Lloyd and North Shore aquifers PDF (32.8 MB)). Wells screened in the Pleistocene deposits of the North Shore aquifer in northern Nassau County are included because in these areas the North Shore aquifer is hydraulically connected to the Lloyd aquifer (Stumm, 2001; Stumm and others, 2002 and 2004). The northern limit of the Lloyd aquifer, the extent of the North Shore aquifer, and the aquifer in which each well is screened, are indicated on this map.

The general configuration of the potentiometric-surface altitude in the Lloyd aquifer is similar to those in the overlying water-table and Magothy aquifers. The potentiometric surface gradually rises from the western part of Long Island to form an east-west-trending mound in eastern Nassau County that continues east into central Suffolk County. The mound then gradually declines toward the eastern end of Long Island.

The potentiometric-surface altitude in the Lloyd aquifer on Long Island in 2006 ranged from about $4 \mathrm{ft}$ above NGVD 29 in northwestern Nassau County to more than $60 \mathrm{ft}$ above NGVD 29 in northeastern Nassau County. In Kings County, 2 measurements ranged from 5.73 to $6.49 \mathrm{ft}$; in Queens County, 6 measurements ranged from 6.18 to $18.60 \mathrm{ft}$; in Nassau County, 45 measurements ranged from 4.25 to $61.16 \mathrm{ft}$; and in Suffolk County, 6 measurements ranged from 18.10 to 39.59 above NGVD 29.

\section{Depth to Water Table}

This map depicts the depth to the water table beneath Long Island in March-April 2006 (Sheet 4 - Depth to water table PDF (34.9 MB)). A geographic information system was used to create a continuous surface of the water table using a nearest neighbor interpolation of 342 measurements at observation wells, interpreted 10 - $\mathrm{ft}$ contour intervals, and the coastline. The altitude of this surface was subtracted from the altitude of the same location in a 10-meter digital elevation model of the topography of Long Island, and the results are shown.

The general configuration of the depth to the water table reflects the topography data; however, because the map scales of the topography $(1: 24,000)$ and water-table altitude $(1: 125,000)$ differ, the horizontal accuracy of the depth to water table is $1: 125,000$ and has a vertical error of $\pm 5 \mathrm{ft}$. Areas in which no water-level data were available for comparison are 
shown in gray; however, in areas along the south shore of Long Island, including marshes and the barrier island, the water-table altitude was assumed to be NGVD 29. Areas in which the water table is shallow are shown in red and indicate areas where potential substructure flooding may occur.

\section{Ground-Water Level Data}

Ground-water level data were downloaded from the USGS National Water Information System (NWIS) database, accessed at http://waterdata.usgs.gov/nwis/si. This database consists of more than 850,000 records of wells, springs, test holes, tunnels, drains, and excavations in the United States. Available site descriptive information includes well-location and completion information, such as latitude, longitude, well depth, and aquifer. NWIS water-level data may be queried and used to construct historical time-series hydrographs for wells. As an example, for Suffolk County mapped well "S16783" search NWIS on Site Name "16783", and chose match any part; then click submit. A search will be performed and a resulting list of site numbers will appear, click on the site number link, then click on the field ground-water-level measurements link.

\section{References Cited}

Smolensky, D.A., Buxton, H.T., and Shernoff, P.K., 1989, Hydrologic framework of Long Island, New York: U.S. Geological Survey Hydrologic Investigations Atlas HA-709, 3 sheets, scale 1:250,000.

Soren, Julian, and Simmons, D.L., 1987, Thickness and hydrogeology of aquifers and confining units below the upper glacial aquifer on Long Island, New York: U.S. Geological Survey Water-Resources Investigations Report 86-4175, 3 sheets, scale 1:125,000.

Stumm, Frederick, 2001, Hydrogeology and extent of saltwater intrusion of the Great Neck peninsula, Great Neck, Long Island, New York: U.S. Geological Survey Water-Resources Investigations Report 99-4280, 41 p.

Stumm, Frederick, Lange, A.D., and Candela, J.L., 2002, Hydrogeology and extent of saltwater intrusion on Manhasset Neck, Nassau County, New York: U.S. Geological Survey WaterResources Investigations Report 00-4193, 42 p.

Stumm, Frederick, Lange, A.D., and Candela, J.L., 2004, Hydrogeology and extent of saltwater intrusion in the northern part of the town of Oyster Bay, Nassau County, New York: U.S. Geological Survey Water-Resources Investigations Report 03-4288, 55 p. 